\title{
CUSTOMER-BASED BRAND EQUITY CREATION FOR ONLINE GROCERY STORES
}

\author{
*Miglė Šontaitė-Petkevičienė \\ Vytautas Magnus University, Lithuania \\ *Corresponding author's email: migle.sontaite-petkeviciene@vdu.lt
}

\begin{abstract}
Given the growing worldwide tendencies of online shopping and increasing popularity of online grocery shopping, building customer-based brand equity for online grocery stores is gaining its popularity among business owners and marketers. Building good customer-based brand equity is considered to be one of the crucial goals for online businesses that leads to successful competition and good customer experience. The aim of this research is to determine customer-based brand equity dimensions for online grocery stores. To reach the aim, this paper adopts analysis and synthesis of scientific and practical literature in the field of customer-based brand equity and empirical research of three stages: field analysis, expert interviews and customer survey. 33 dimensions of customer-based brand equity for online grocery stores grouped in 8 dimension clusters were generated from the field analysis and expert interviews. Generated dimensions were provided for the evaluation during the customer survey. Empirical research proved 31 valid dimensions of customer-based brand equity for online grocery stores evaluated as very relevant, relevant and of average relevance. Main drivers of customer-based brand equity for online grocery stores that proved to be very relevant are: saving time, good price, fresh products, quality of service, and reputation of retail chain behind.
\end{abstract}

Key words: customer-based brand equity, brand equity, branding, customer behaviour, e-commerce, retail.

\section{Introduction}

The construct of customer-based brand equity has gained a wide interest from theory as well as practice. Creation of customer-based brand equity has become one of the most important tendencies in branding and management of business organizations. In addition, online retailers are coming to realize that they have much to learn in this area and that customer-based brand equity is particularly appealing in the online shopping. Despite the fact that Lithuania and other EU countries are living in the world of booming popularity of online grocery shopping, customer-based brand equity creation for online grocery stores is quite a new topic. It is argued that this field lacks knowledge and tools to build value for customers. Consequently, the question is not whether online grocery stores should build customer-based brand equity but how it should be done.

This paper focuses on dimensions of customerbased brand equity for online grocery stores. The purpose of this research is to answer the question how to build customer-based brand equity for online grocery stores. The object of the research is customerbased brand equity for online grocery stores. The aim of this research is to determine customer-based brand equity dimensions of online grocery stores.

The objectives of the paper are as follows: to analyse theoretical conceptualizations of customerbased brand equity and its creation; to identify customer-based brand equity dimensions for online grocery stores by using field analysis and expert interviews; to evaluate the relevance to customerbased brand equity dimensions of online grocery stores by using customer survey method.

The paper consists of both theoretical and empirical analysis. The research methods used in the paper include logical analysis, generalization and interpretation of scientific and practical literature. After the presentation of theoretical insights, research methodology is outlined, following with empirical research findings. Finally, conclusions are stated.

Given the intensified competition in the retail industry and booming popularity of online groceries shopping, a better understanding of customer-based brand equity is strategically important for online grocery stores. Consumer-based brand equity receives significant attention from the academic and business communities (Cifci et al., 2016); however, a review of customer-based brand equity literature demonstrates that: (a) despite the rich literature on customer-based brand equity, lack of consensus on its conceptualization and operationalization remains; (b) most of the studies focus on a limited number of customer-based brand equity facets, thus failing to provide a more holistic view of the customer-based brand equity process; (c) there is a scarcity of studies that integrate key consumer behavioural outcomes into the customer-based brand equity formation process (Chatzipanagiotou, Christodoulides, \& Veloutsou, 2019). Anselmsson, Burt \& Tunca (2017) draw attention to the fact that retailers are amongst the world's strongest brands, but little is known about retailer customer-based brand equity. They argue that current operational models are too abstract for understanding the uniqueness of the retail industry and too simplistic to understand the interrelationships among the dimensions in the retailer brand equity building process.

Various authors agree that consumer-based brand equity provides a number of positive outcomes for organizations. Consumer-based brand equity is essential for driving customer equity, differentiating brands, assessing brand performance and gaining competitive advantage in the marketplace (Cifci et al., 2016). Keller, Aperia \& Georgson (2012) argue 
that a brand with positive customer-based brand equity results in consumers being more accepting of a brand extension, less sensitive to price increases and withdrawal of advertising support or more willing to seek the brand in a new distribution channel. Troiville, Hair \& Cliquet (2019) add that retailer customerbased brand equity affects customer attitude, loyalty and word-of-mouth. An example of the importance of retailer brand equity is evidenced by the annual report of Deloitte (2019): retailers have to find ways to distinguish themselves from competitors in order to succeed. That means having strong customer-based brand equity, offering consumers superior shopping experiences, and being clearly differentiated from competitors. Customer-based brand equity appears to be a major construct and retailers should take advantage of it because the equity of the retailer should serve to increase the retailers: a) share of wallet (by increasing the money spent in its owned stores); b) market share (by adding up the current and new customers due to its attraction); c) power against competitors within the marketplace; d) bargaining power against manufacturers and suppliers in the vertical channel; e) efficiency (by a cost reduction); and f) revenue and profits (Troiville, Hair, \& Cliquet, 2019).

Keller, Aperia \& Georgson (2012) define customer-based brand equity as the differentiated effect that brand knowledge has on consumer response to the marketing of that brand. A brand is said to have positive customer-based brand equity when consumers react more favourably to a product and the way it is marketed when the brand is identified than when it is not. However, Troiville, Hair \& Cliquet (2019) argue that a specific conceptual definition adapted to retailers remains to be developed and validated.

Keller, Aperia \& Georgson (2012) distinguish two main sources for customer-based brand equity: brand awareness and brand image. According to Aaker (1991), customer-based brand equity has four dimensions: perceived quality, brand awareness, brand loyalty and brand associations. Cifci et al. (2016) distinguish 6 customer-based brand equity dimensions: brand awareness, physical, staff behaviour, ideal self-congruence, brand identification, lifestyle-congruence. Nam, Ekinci \& Whyatt (2011) argue that customer-based brand equity is created based on 7 dimensions: physical quality, staff behaviour, ideal self-congruence, brand identification and lifestyle congruence, brand satisfaction and brand loyalty.

However, Troiville, Hair \& Cliquet (2019) believe that existing customer-based equity frameworks are usually product-based and, consequently not appropriate and should not be used when it comes to conceptualizing the brand equity of retailers.
Anselmsson, Burt \& Tunca (2017) agree to this notion stating that there are several examples of retailer equity scales, but because these scales are based on general models, they currently fail to capture important dimensions that are unique to the retailing industry. As Troiville, Hair \& Cliquet (2019) explains, retailers typically build customer-based brand equity by enhancing the product value and the experiential value, but still have no effective means to operationalize and measure it.

Anselmsson, Burt \& Tunca (2017) argue that retailer specific dimensions should be better reflected in retailer brand equity measurement models. Troiville, Hair \& Cliquet (2019) in their research distinguished 7 retailer customer-based brand equity dimensions: access, assortment, atmosphere, convenience, employees, quality, value and private brands. While Anselmsson, Burt \& Tunca (2017) presented a retailer brand equity scale, which as they say provides high predictability of core dimensions such as brand trust and loyalty and, is comprehensive including both general brand equity dimensions and retail industry specific dimensions. Their scale consists of 17 items grouped to 4 factors: awareness, product quality, customer service, pricing policy, retailer trust, physical store, loyalty.

Existing frameworks prove that customerbased brand equity frameworks are context specific. Therefore, it is possible to argue that customer-based brand equity dimensions of online grocery stores might be different. That is why it is possible to state that customer-based brand equity should be treated in terms of specific industries meaning customerbased brand equity of online grocery stores might demonstrate specifics compared to other industries.

\section{Materials and Methods}

To achieve the aim of the paper, this research adopts analysis and synthesis of scientific and practical literature in the field of customer-based brand equity creation. In order to theoretically determine how customer-based brand equity is built and managed, general scientific research methods were applied - systematic analysis, evaluation, generalization, comparison and abstraction.

Furthermore, to identify customer-based brand equity dimensions of online grocery stores, the empirical research was carried out. Three different empirical research methods have been used: qualitative field analysis, expert interviews and customer survey. At first, field analysis of market data from secondary sources was performed. Qualitative field analysis, as well as findings of academic and scientific researches helped to construct the set of customer-based brand equity dimensions for the online grocery stores. These findings were discussed during the following 
Methods of empirical research

\begin{tabular}{|c|c|c|c|}
\hline \multirow[t]{2}{*}{ Parameters of research } & \multicolumn{3}{|c|}{ Research methods and their characteristics } \\
\hline & First stage of research & Second stage of research & Third stage of research \\
\hline 1. Nature of research & Exploratory research & Exploratory research & Descriptive research \\
\hline 2. Object of research & \multicolumn{3}{|c|}{ Dimensions of customer-based brand equity for online grocery store } \\
\hline 3. Order of research & \multicolumn{3}{|c|}{ Onetime (short-term) } \\
\hline 4. Level of research & \multicolumn{3}{|c|}{ National } \\
\hline 5. Type of data & Secondary data & \multicolumn{2}{|c|}{ Primary data } \\
\hline 6. Method of research & Field analysis & Semi-structured interviews & Survey on internet \\
\hline $\begin{array}{l}\text { 7. Instrument of data } \\
\text { collection }\end{array}$ & $\begin{array}{l}\text { Online search using } \\
\text { keywords }\end{array}$ & Questionnaire & Questionnaire \\
\hline 8. Type of questions & - & Open & $\begin{array}{l}\text { Open and closed (scale } \\
\text { and optional) }\end{array}$ \\
\hline 9. Type of scale & - & - & Likert scale \\
\hline 10. Number of values & - & - & 5 \\
\hline 11. Method of measurement & Qualitative & Qualitative & Quantitative \\
\hline 12. Sample of research & - & \multicolumn{2}{|c|}{ Purposive nonprobability } \\
\hline
\end{tabular}

step - conducting interviews with representatives of online grocery stores. Insights collected during expert interviews amended collected data with the internal point of view. Finally, at the third stage of empirical research - the anonymous online customer survey has been performed. Methods used during empirical research are outlined in Table 1.

Field analysis. Secondary data from external sources was used to perform field analysis, which includes online grocery stores market overview in Lithuania. Online grocery stores market presentation is based on external data by evaluating product portfolio structure, competitive advantage, resources, capabilities, market development trends and possible dimensions of customer-based brand equity.

Expert interviews. In order to gather internal insights on customer-based brand equity creation for online grocery stores, informal semi-structured interviews have been performed. Live interview method was chosen in order to gather primary data from the representatives of 2 online grocery stores that operate in Lithuania. An individually prepared questionnaire was used as the basis for these interviews. Two marketing managers representing two different online grocery stores were asked to share their ideas about the current setup of the company (and its suitability to serve customers' needs efficiently), current customer-based brand equity creation status and future vision and the main challenges related to this issue. The interviews were conducted in the form of live meetings and discussions, providing guidance for possible answers and asking for clarification or elaboration if necessary. The questionnaire for expert interviews consisted of 9 open questions. Before starting interviews, experts were introduced with the aim of the discussion, its logic and expected result. Semi-structured interviews were organized in January, 2020. The duration of each interview was $~ 15-30$ minutes.

As the exploratory research can only describe content of problem, generate ideas and insights, and determine variables for the descriptive research, results of exploratory research were considered mediate and modifiable during the descriptive research. Data from questionnaires helped to determine dimensions of customer-based brand equity from the point of view of online grocery stores' representatives, provided information which aspects of customer-based brand equity are considered as the most important by the companies. Based on the insights collected from the expert interviews, customer survey questionnaires were prepared.

Customer survey. The survey was constructed and distributed using a web-based platform SurveyMonkey. 342 questionnaires that were collected during descriptive research were processed and analysed. It is presumed that a sample of descriptive research was representative. Answers from customer survey allowed to identify and evaluate customer-based brand equity dimensions that are most important for the customers of online grocery stores. To participate in the survey respondents had to comply with one condition - to be a customer of online grocery store. This means that they had to purchase at least once from at least one of the online grocery stores. Respondents of customer survey were asked to evaluate the importance of customer-based brand equity dimensions for the online grocery store. 
Evaluation of the online grocery stores' customerbased brand equity dimensions allowed to calculate average meanings of each dimension and distinguish most important aspects that online grocery stores should focus on while building their customer-based brand equity. Since this empirical research is a threestage research using three different research methods, it is considered to provide trustworthy results.

\section{Results and Discussion}

This section provides results from three stages of empirical research: qualitative analysis, expert interviews and customer survey.

Field analysis. Field analysis of market data from secondary sources was performed in order to do an online grocery stores' market overview. Lithuanian online grocery stores market was analysed by evaluating product portfolio structure, competitive advantages, resources, capabilities, market development trends and possible dimensions of customer-based brand equity. Results from the field analysis allowed to determine the level of customerbased brand equity that Lithuanian online grocery stores are building and identify possible dimensions of customer-based brand equity for online grocery stores.

First online grocery store in Lithuania Zzz.lt was introduced into the market in 2015. Two years later, it stopped its existence. They had a hard task - to change Lithuanians' buying behaviour, educate people and earn trust, since they were innovators in Lithuanian market - first online grocery store. Another important reason for their failure was considered the fact that it was a start-up without any retail chain behind. However, their ambitions were very big - they started from zero in all Lithuanian cities right away from the beginning.

At the moment, two online grocery stores operate in Lithuania: Barbora (as part of Maxima group) and LastMile (partner of IKI retail chain). Both online grocery stores - Barbora and LastMile - are introduced into the market by different Lithuanian retail chains. Following the tendencies of online shopping growth, another retail chain Rimi has plans to introduce their online grocery store to market in 2020 first quarter. This will be the third player in deliberately small Lithuanian market.

Retail chain Maxima introduced Barbora brand into Lithuanian market in 2014. This online grocery store was first introduced into two largest cities of Lithuania - Vilnius and Kaunas. In 2017, Barbora started operating in Klaipeda, too. At the moment, Barbora operates in 11 Lithuanian cities. In 2018, Barbora entered Latvian and Estonian markets (Budzinauskiene, 2018). In 2018, the growth of Barbora reached $50 \%$, mostly influenced by its market expansion (M360, 2019). CEO of Barbora in his interview highlighted main priorities of Barbora: further development, improvement of services quality and customer experience, introduction of innovative and environment friendly solutions (M360, 2019). Main advantages for customers outlined in Barbora. lt webpage are as follows: saving precious time of customers; taking advantage of attractive offers and discounts; selection of fresh and high-quality products; receipt of $1 \%$ on the amount of purchases in Maxima money (Barbora official website, 2020). Barbora brand's slogan is 'More time for yourself'. In 2018, Barbora introduced a new technology for order pickup - 'Click\&Collect' self-service food terminals with 3 different temperature zones. CEO of Barbora stated that the new technology provides more opportunities for customers, allows better time planning, customers do not depend on currier arrival time, and it allows to pick up order when Barbora is closed (Budzinauskienè, 2018). Barbora delivers order by using highly recognizable red trucks that has a visible brand and ensures required temperature for product deliveries. Customers can pay for their orders using different payment methods. Barbora online grocery store offers wide selection of vegetables, fruits, meat, bakeries, dairy products, drinks and commodity goods. CEO of Barbora distinguishes quality as their main goal. In the future, they intend to expand their product portfolio and offer express delivery service. Another important development direction is expansion of service offering customers a wide selection and freedom. Third direction is attention to citizenship and waste reduction (Juškauskaitè, 2019).

In 2019, another online grocery store started delivering groceries to Lithuanians. Lithuanian people had the possibility to order groceries from physical retail store IKI by using an app of Lithuanian startup LastMile. They started in Vilnius. However, few months later another city - Kaunas - was added (Mikoliūnaite, 2019). Their competitive advantage was based on a shared economy principle as LastMile allows orders and deliveries not only from IKI, but also from other shops. LastMile positions itself as an online shopping centre that has many shops (Vizbarienè, 2019). Differing from their main competitor - Barbora, they use independent couriers for the deliveries. Another competitive advantage is very fast delivery of fresh products. As a marketing manager of LastMile stated, their significance is speed of delivery, they call it an instant delivery. None of the competitors can offer faster delivery, because they use shared economy model when deliveries are made by citizens (Chockevičiūtè, 2019). Also, this helps to build LastMile brand as a socially responsible brand. Communication manager of IKI states that they are researching possibilities for improved customer experience, usage of technological advantages and 
Dimensions of customer-based brand equity for online grocery store

\begin{tabular}{|c|c|c|c|c|c|}
\hline $\begin{array}{l}\text { Clusters of } \\
\text { dimensions }\end{array}$ & Dimensions & \multicolumn{2}{|c|}{ Source } & \multicolumn{2}{|r|}{ Relevance } \\
\hline \multirow{5}{*}{ Customer focus } & customer experience & FA & & 4.3 & Relevant \\
\hline & quality of service & FA & EI & 4.5 & Very relevant \\
\hline & customer service & FA & EI & 4.3 & Relevant \\
\hline & convenient app & FA & & 4.1 & Relevant \\
\hline & word-of-mouth & & EI & 3.9 & Relevant \\
\hline \multirow{4}{*}{ Product quality } & wide product portfolio & FA & & 4.1 & Relevant \\
\hline & fresh products & FA & & 4.6 & Very relevant \\
\hline & high quality products & FA & EI & 3.8 & Relevant \\
\hline & value for money & FA & & 4.4 & Relevant \\
\hline \multirow{5}{*}{$\begin{array}{c}\text { Delivery } \\
\text { amenities }\end{array}$} & fast delivery & FA & EI & 4.4 & Relevant \\
\hline & express delivery (within 1 h 30 min) & FA & & 3.0 & Average relevance \\
\hline & free delivery & FA & & 4.2 & Relevant \\
\hline & deliveries by independent couriers (citizens) & FA & & 2.3 & Low relevance \\
\hline & saving time & & EI & 4.8 & Very relevant \\
\hline \multirow{4}{*}{$\begin{array}{c}\text { Financial } \\
\text { benefits }\end{array}$} & good price & FA & & 4.7 & Very relevant \\
\hline & attractive offers and discounts & FA & & 4.3 & Relevant \\
\hline & money returns from purchases, retail chain money & FA & & 2.9 & Average relevance \\
\hline & collection of points & FA & & 2.4 & Low relevance \\
\hline \multirow{3}{*}{$\begin{array}{l}\text { Alternative } \\
\text { choices }\end{array}$} & self-service food terminals & FA & & 3.7 & Relevant \\
\hline & different payment methods & FA & & 3.9 & Relevant \\
\hline & possibility to combine shops in one order & FA & & 4.2 & Relevant \\
\hline \multirow{2}{*}{ Innovativeness } & innovative solutions & FA & & 3.6 & Relevant \\
\hline & new services & FA & & 3.2 & Average relevance \\
\hline \multirow{5}{*}{ Brand } & reputation of retail chain behind & FA & & 4.5 & Very relevant \\
\hline & brand awareness & FA & & 4.1 & Relevant \\
\hline & brand associations & & EI & 4.3 & Relevant \\
\hline & trustworthy brand & & EI & 4.2 & Relevant \\
\hline & market influencer & & EI & 4.0 & Relevant \\
\hline \multirow{5}{*}{ Responsibility } & environment friendly solutions & FA & & 3.8 & Relevant \\
\hline & citizenship & FA & & 3.3 & Average relevance \\
\hline & waste reduction & FA & & 3.6 & Relevant \\
\hline & eco-friendly packaging & FA & & 3.9 & Relevant \\
\hline & socially responsible brand & FA & & 4.2 & Relevant \\
\hline
\end{tabular}

Note: sources are coded (FA-field analysis, EI-expert interviews).

offering qualitative assortment and time saving (Juškauskaitè, 2019).

As the rest of retail chains that operate in Lithuania - Lidl and Norfa - are also planning of starting online groceries shopping possibilities - it is worth to analyse what dimensions of existing online grocery stores build customer-based brand equity. The results would help the later competitors to have a more successful start of business and build value to customers from the first days of existence.
Based on the qualitative field analysis it is possible to identify possible customer-based brand equity dimensions for the online grocery stores. After analysis of publications in the media and retail chains' websites the author of this paper was able to distinguish 28 possible dimensions of customer-based brand equity for the online grocery stores: fast delivery; express delivery (within $1 \mathrm{~h} 30$ min); customer experience; innovative solutions; environmentally friendly solutions; attractive offers 
and discounts; wide product portfolio; fresh products; high quality products; money returns from purchases, retail chain money; collection of points; self-service food terminals; reputation of retail chain behind; brand awareness; value for money; different payment methods; good price; quality of service; new services; citizenship; waste reduction; eco-friendly packaging; convenient app; possibility to combine shops in one order; free delivery; deliveries by independent couriers (citizens); socially responsible brand; customer service. The above mentioned 28 possible dimensions extracted from the field analysis are listed in Table 2 using a code FA (field analysis).

Expert interviews. Second stage of empirical research - expert interviews - were done in order to gather internal insights on customer-based brand equity dimensions for online grocery stores. Live informal semi-structured interviews have been performed with representatives of 2 Lithuanian online grocery stores - Barbora and LastMile. Two marketing managers representing both online grocery stores were asked to share their ideas about the current setup of the company (and its suitability to serve customers' needs efficiently), current customer-based brand equity creation status and future vision, the main challenges related to this issue.

Experts informed about customer surveys confirming the prominence of positive brand associations towards both online grocery stores. Interviewees highlighted that customers appreciate good customer service, product quality, saving time, fast deliveries. All those advantages help to build the image of trustworthy brand. Both interviewees were happy to mention that the majority of customers after trying the service become loyal clients. They value loyal customers as they help to build brand awareness, by recommending this service to others. Word of mouth is a very powerful tool of communication and branding.

When interviewees were asked to distinguish their target customer, marketing manager from Barbora characterized their target customer as an inhabitant of Vilnius, Kaunas and Klaipèda regions, having average and higher than average income, open for innovations and price insensible. To be more specific, he described a target customer of Barbora as mother who finds it convenient to order groceries delivery and a young businessman who does not want to spend his precious time standing in line at the shop. Also, it is a business client. Marketing manager from LastMile stated that their target customer is an inhabitant of largest Lithuanian cities, open for innovations, price sensitive that values speed of delivery.

Both representatives of Lithuanian online grocery stores mentioned that their main goal is to help their customers to save precious time and offer good quality service. Other possible dimensions of customerbased brand equity mentioned during the interviews were: positive brand associations; good customer service; product quality; fast deliveries; trustworthy brand; market influencer; word of mouth. The above mentioned 9 possible dimensions of customer-based brand equity for the online grocery stores extracted from the expert interviews are listed in Table 2 using a code EI (expert interview).

Customer survey. The quantitative survey with customers allowed to evaluate each possible customerbased brand equity dimension and their level of relevance for the customers of online grocery stores. Possible customer-based brand equity dimensions for the customers of online grocery stores that were provided for the evaluation during customer survey are listed in Table 2. After collection of customer responses, collected data was analysed and average meanings for dimension were calculated.

Table 2 summarizes the results from the customer survey providing average meanings for each evaluated dimension and the level of relevance. The maximum possible average meaning is 5 and such an evaluation indicates the highest relevance. Dimensions that are as close as possible to the average meaning of 5 (4.5-5) can be considered as very relevant customer-based brand equity dimensions for the online grocery stores. Average meanings between $3.5-4.4$ are considered as relevant dimensions. And average meanings between 2.5-3.4 are considered as having average importance. Average meanings 2.4 and below are considered as having low relevance meaning; they should not be considered as dimensions that build customer-based brand equity for online grocery stores.

Results from the customer survey show that 31 dimensions out of 33 can be considered as valid dimensions of customer-based brand equity for online grocery stores. This conclusion is made due to the fact that 31 dimension received average meaning 2.5 and higher showing that almost all evaluated dimensions were either very relevant (4.5-5), relevant (3.5-4.4.) or had average relevance (2.5-3.4). Results from customer survey indicated that customer-based brand equity of online grocery stores can be built based on 5 very relevant dimensions, 22 relevant dimensions and 4 dimensions that have average relevance.

Main drivers of customer-based brand equity for online grocery stores that proved to be very relevant are: saving time (4.8); good price (4.7); fresh products (4.6); quality of service (4.5); reputation of retail chain behind (4.5). Those 5 dimensions represent 5 different clusters of dimensions: customer focus, product quality, delivery amenities, financial benefits and brand.

Dimensions that have lower relevance, however are still important dimensions of customer-based brand 
equity for online grocery stores, are 22 dimensions: value for money (4.4); fast delivery (4.4); customer experience (4.3); customer service (4.3); attractive offers and discounts (4.3); brand associations (4.3); trustworthy brand (4.2); free delivery (4.2); possibility to combine shops in one order (4.2); socially responsible brand (4.2); convenient app (4.1); wide product portfolio (4.1); brand awareness (4.1); market influencer (4.0); word-of-mouth (3.9); eco-friendly packaging (3.9); different payment methods (3.9); environmentally friendly solutions (3.8); high quality products (3.8); self-service food terminals (3.7); innovative solutions (3.6); waste reduction (3.6). All 22 dimensions represent all clusters of dimensions.

Four dimensions were proved as having average relevance for customer-based brand equity of online grocery stores: citizenship (3.3); new services (3.2); express delivery (within $1 \mathrm{~h} 30 \mathrm{~min}$ ) (3.0); money returns from purchases, retail chain money (2.9). These dimensions can be considered as the aspects that online grocery stores should put less efforts if at all.

Dimensions that were confirmed as not relevant for building customer-based brand equity of online grocery stores were deliveries by independent couriers (citizens) (2.3) and collection of points (2.4). One of the mentioned dimensions - deliveries by independent couriers (citizens) - is considered as competitive advantage of one of the analysed online grocery stores. This suggests that one of the analysed online grocery stores should consider carefully if this dimension is worth the investment. However, if this dimension is used to save costs and strengthen other dimensions like fast delivery, customer experience, innovative solutions or others, then it is considered as reasonable.

\section{Conclusions}

1. Based on the analysis of scientific and practical literature, it is possible to conclude that a better understanding of customer-based brand equity is strategically important for online grocery stores. Consumer-based brand equity receives a significant attention from the academic and business communities; however little is known about retailer customer-based brand equity. Current frameworks are too abstract for understanding the uniqueness of the retail industry and too simplistic to understand the interrelationships among the dimensions in the retailer brand equity building process. Existing customer-based equity frameworks are usually product-based and, consequently should not be used when it comes to conceptualizing the brand equity of retailers, because they fail to capture important dimensions that are unique to the retailing industry.

2. During the empirical research it was possible to determine relevant dimensions of customer-based brand equity for online grocery stores. Five most important dimensions that online grocery stores should focus most while building their customerbased brand equity are: saving time, good price (financial benefits cluster), fresh products (product quality cluster), quality of service (customer focus cluster), reputation of retail chain behind (brand cluster). Other 22 dimensions were proved to be relevant customer-based brand equity dimensions for online grocery stores. Four dimensions were proved as having average relevance (citizenship, new services, express delivery, money returns from purchases, retail chain money). Dimensions that were confirmed as not relevant are deliveries by independent couriers (delivery amenities cluster) and collection of points (financial benefits cluster). They should be excluded from variables list when building customer-based brand equity for online grocery stores.

3. Since the results of empirical research are representative and show what creates value for customers of online grocery stores, results from this empirical research could be applied widely when creating online shopping solutions for customers. Results could be used by existing and future online grocery stores. Results might be context specific, so the initial list of dimensions should be tested contextually.

\section{References}

Aaker, D.A. (1991). Managing brand equity: capitalizing on the value of a brand name. New York: Free Press. Anselmsson, J., Burt, S., \& Tunca, B. (2017). An integrated retailer image and brand equity model: Reexamining, extending, and restructuring retailer brand equity. Journal of Retailing and Consumer Services. 38, 194-203. DOI: 10.1016/j.jretconser.2017.06.007.

Barbora official website (2020). Retrieved March 11, 2020, from https://www.barbora.lt/?\&subcat=8348220cabdc-4dba-a97c-052e05d5b91c \&SortBy=brand \& \& subcat $=8348220$ c-abdc-4dba-a97c052e05d5b91c\&SortBy=brand. (in Lithuanian).

Budzinauskienè, E. (2018). 'Barbora' Vilniuje pastatè pirmuosius paštomatus ('Barbora' introduced first selfservice food terminals in Vilnius). Retrieved March 11, 2020, from https://www.delfi.lt/verslas/verslas/ barbora-vilniuje-pastate-pirmuosius-maistomatus.d?id=79845553. (in Lithuanian). 
Chatzipanagiotou, K., Christodoulides, G., \& Veloutsou, C. (2019). Managing the consumer-based brand equity process: A cross-cultural perspective. International Business Review. 28, 328-343. DOI: 10.1016/j. ibusrev.2018.10.005.

Chockevičiūtè, V. (2019). Lietuvių startuolis meta iššūki 'Barborai': pažadas prekes pristatyti per pusvalandị (Lithuanian startup challenges 'Barbora': promise to deliver in half an hour). Retrieved March 11, 2020, from https:/www.delfi.lt/verslas/verslas/lietuviu-startuolis-meta-issuki-barborai-pazadas-prekespristatyti-per-valanda.d?id=81819749. (in Lithuanian).

Cifci, S., Ekinci, Y., Whyatt, G., Japutra, A., Molinillo, S., \& Siala, H. (2016). A cross validation of consumerbased brand equity models: driving customer equity in retail brands. Journal of Business Research. 69, 3740-3747. DOI: 10.1016/j.j.busres.2015.12.066.

Deloitte (2019). Global powers of retailing. Retrieved March 9, 2020, from https:/www2.deloitte.com/content/ dam/Deloitte/global/Documents/Consumer-Business/cons-global-powers-retailing-2019.pdf.

Juškauskaitè, V. (2019). 'Barboros' vienvaldystę sugriauti nebus lengva: šia prabanga gali sau leisti tik turintys gilias kišenes (It won't be easy to destroy 'Barbora' autocracy: this luxury can only be let in by those who have deep pockets). Retrieved March 11, 2020, from https://www.delfi.lt/m360/naujausistraipsniai/barboros-vienvaldyste-sugriauti-nebus-lengva-sia-prabanga-gali-sau-leisti-tik-turintys-giliaskisenes.d?id=82623715. (in Lithuanian).

Keller, K.L., Aperia, T., \& Georgson, M. (2012). Strategic brand management. London: Prentice Hall.

M360 (2019, June). Nuolatinis 'Barboros'Lietuvoje vadovas - A.Mikalauskas (Permanent CEO of 'Barbora' in Lithuania is A.Mikalauskas). Retrieved March 11, 2020, from https://www.delfi.lt/m360/naujausistraipsniai/nuolatinis-barboros-lietuvoje-vadovas-a-mikalauskas.d?id=81352426. (in Lithuanian).

Mikoliūnaite, K. (2019). Konkurencija 'Barborai': maista ì namus užsisakyti galima ir iš 'Iki' (Competition to Barbora: food can be ordered from 'Iki' as well). Retrieved March 11, 2020, from https://www.15min. lt/verslas/naujiena/bendroves/konkurencija-barborai-maista-i-namus-bus-galima-uzsisakyti-ir-isiki-663-1218024. (in Lithuanian).

Nam, J., Ekinci, Y., \& Whyatt, G. (2011). Brand equity, brand loyalty and consumer satisfaction. Annals of Tourism Research. 38(3), 1009-1030. DOI: 10.1016/j.annals.2011.01.015.

Troiville, J., Hair, J.F., \& Cliquet, G. (2019). Definition, conceptualization and measurement of customerbased retailer brand equity. Journal of Retailing and Consumer Services. 50, 73-84. DOI: 10.1016/j. jretconser.2019.04.022.

Vizbarienè, R. (2019). 'Iki' pasiūlè užsisakyti prekiu internetu ('Iki' offered order groceries online). Retrieved March 11, 2020, from https://www.vz.lt/prekyba/2019/10/17/iki-pasiule-uzsisakyti-prekiu-internetu. (in Lithuanian). 